\title{
Big data and analytics in tourism and hospitality: a perspective article
}

Article

Accepted Version

Mariani, M. (2020) Big data and analytics in tourism and hospitality: a perspective article. Tourism Review, 75 (1). pp. 299-303. ISSN 1660-5373 doi: https://doi.org/10.1108/TR-062019-0259 Available at https://centaur.reading.ac.uk/84982/

It is advisable to refer to the publisher's version if you intend to cite from the work. See Guidance on citing.

To link to this article DOI: http://dx.doi.org/10.1108/TR-06-2019-0259

Publisher: Emerald

All outputs in CentAUR are protected by Intellectual Property Rights law, including copyright law. Copyright and IPR is retained by the creators or other copyright holders. Terms and conditions for use of this material are defined in the End User Agreement.

\section{www.reading.ac.uk/centaur}

\section{CentAUR}

Central Archive at the University of Reading

Reading's research outputs online 


\section{Big Data and Analytics in Tourism and Hospitality: A perspective article}

Purpose: This study aims at discussing the evolution of Big Data and Analytics in the tourism and hospitality field. It analyses the important role that Big Data (BD) has played so far in tourism and hospitality research and delineates how it might evolve in the future.

Design/methodology/approach: In line with the Platinum Jubilee Special Issue of Tourism Review, this work consists of a critical and conceptual analysis including a mini literature review of recent work in the area at the intersection of BD and tourism and hospitality research.

Findings: Findings suggest that tourism and hospitality scholars are increasingly aware of and adopting BD approaches to retrieve, collect, analyse, report and visualize their data. However, a number of avenues for improvement in the use and interpretation of BD and BD analytics as both sets of methods and technology need to be developed. Moreover, BD analytics promise to enhance a number of digital technologies in tourism and hospitality such as AI and IoT that heavily rely on data. As such we envision that a new digital entrepreneurship field might be shaped within the tourism and hospitality literature. Research pathways for future inquiry at the intersection of big data and tourism and hospitality are outlined.

Originality/value: While thinking retrospectively about research revolving around BD and its role in the tourism and hospitality research field so far, this study also addresses the challenges pertaining to how BD research will be conducted in the next seven decades within tourism and hospitality.

Keywords: Big data; big data analytics; tourism; hospitality; Platinum Jubilee

\section{Introduction}

Every year human beings and machines increasingly generate vast amounts of data (Hilbert and López, 2011). Today more than the 2.5 Exabytes of data are produced daily (IBM, 2016). The advent and consolidation of the Internet, the proliferation of smartphones and Internet of Things (IoT) devices and sensors is contributing to reinforce this growing trend. As such, we live in a data world and businesses in a data economy where data is actually the new oil propelling economic growth (The Economist, 2017). The tourism and hospitality $(\mathrm{T} \& \mathrm{H})$ sectors are not an exception and tourism destinations, firms and consumers increasingly create and deploy large volumes of data to improve their decision making processes and co-create value (Mariani et al., 2014; Mariani, Mura and Di Felice, 2018; Pauleen and Wang 2017; Pigni et al., 2016). For instance, tourists' location data tracked by means of GPS sensors embedded in smartphones can provide destination marketers with meaningful insights about the most popular routes and attractions in a destination; when matched with social media data, location data allow marketing firms to create location-specific offers based on the preferences and behaviors that the consumer has revealed on social media in the past, thus allowing businesses to interact in real time with potential customers based on the opinions and actions that they share and on the history of their preferences and tastes. Furthermore, Online Travel Agencies (OTAs) can leverage on large volumes of structured and unstructured data stemming from online travel reviews to better understand tourists' online behaviours by means of digital data analytics (Mariani, Di Fatta and Di Felice, 2019). This work looks retrospectively at the way this overabundance of travel and tourism related data, namely Big Data (BD), has been made sense of, and examined in $\mathrm{T} \& \mathrm{H}$ literature and illustrates future research directions. 


\section{Past perspective 75 years of developments 1946-2020}

The "Big Data" (BD) concept appeared in the late Nineties in computer science literature in relation to scientific visualization (Cox and Ellsworth, 1997). However, its first definition was given in 2001 by Doug Laney who identified three major characteristics of BD as the 3Vs: Volume (size of data, in the order of Zettabytes), Velocity (rapidity of data generation, modification and transfer), and Variety (data can assume different formats/structures). Later the definitional model was perfected by introducing the Vs of Value (the process of extracting valuable knowledge from data by means of BD analytics) and Veracity (the governance of data in relation to their reliability) thus leading to the formulation of a 5Vs framework (Bello-Orgaz et al., 2016).

As observed in a recent systematic literature review (Mariani et al., 2018), research on the role of BD in T\&H is still rather fragmented and "relegated to isolated research questions" (Mariani et al., 2018: 3516). Based on the aforementioned literature review matched with a further review of articles published in the years 2017-2019, we draw some reflections on extant research. First, scholars seem increasingly interested in adopting large volumes of data to better understand complex tourism and hospitality phenomena as witnessed by an increase in the number of articles explicitly adopting BD and BD analytics (e.g., Liu et al., 2018; Mariani and Borghi, 2018; Talón-Ballestero et al., 2018). However this body of research is a marginal share of the studies produced in the T\&H field. Second, while articles have adopted different sources of data, the majority of BD articles in tourism relies on one specific source which is UGC data (e.g., social media post and online travel reviews), followed by location data (e.g., GPS data), and travel information search data. This is certainly not in line with the notion that BD studies should employ and triangulate a variety of sources and formats of data (e.g., Sun et al., 2019). Third, in terms of techniques deployed, while traditional regression analyses are still dominant, increasingly text analytics are deployed, as well as machine learning techniques. However, artificial intelligence or Bayesian classification methods are extremely rare. Fourth, as far as research streams are concerned, it seems that eWOM research is the most reliant on the use of BD to dig in depth about online travellers' preferences, behaviours, satisfaction, and mobility (e.g., Mariani and Borghi, 2018) and increasingly about firms' efficiency (Mariani and Visani, 2019). Last, it seems that analytics (especially text analytics) are becoming increasingly relevant in a number of studies (Xiang et al., 2017; Zhao et al., 2019).

\section{Future perspective 75 years 2020-2095}

It is envisioned that the research field of $\mathrm{T} \& \mathrm{H}$ will increasingly embrace $\mathrm{BD}$ and $\mathrm{BD}$ analytics at different levels, speed and for different purposes. In particular, BD will increasingly contribute to: 1) frame novel research questions and hypotheses if combined with an underpinning conceptual framework; 2) enrich research designs and methods; 3) improve the generalizability of research findings across different institutional, economic, social and geographical contexts; 4) generate relevant managerial insights and business intelligence by means of (digital) data analytics in real time; 5) advance BD technological applications in the verticals of tourism and hospitality.

However, in order to make the aforementioned contributions and seize the related opportunities, there are a few challenges that need to be addressed. First, T\&H scholars will still need to rely on an overarching conceptual framework identifying critical business problems in T\&H (Fuchs et al., 2016) despite early attempts to develop it (Stylos and Zwiegelaar, 2019). As such BD will likely bring to a situation whereby theory and data analytics capabilities (Davenport, 2017) will need to further consolidate and corroborate an emerging fertile dialogue. However, to address the aforementioned challenge, scholars should increasingly work in cross-disciplinary research teams including data and computer scientists (Mariani et al., 2018). Second, BD offer the opportunity to enrich research designs and methods as they might be progressively embedded in mixed methods (Creswell, 2014) such as explanatory/exploratory sequential designs whereby big and small data might be juxtaposed, 
combined and triangulated. This approach to data might call for the introduction of a new data lifecycle paradigm (Blazquez and Domenech, 2018). In terms of methods, unsupervised machine learning will probably gain momentum as well as Artificial Intelligence (AI). Third, while the retrieval of large volumes of varied data in real time might generate an opportunity to overcome generalization issues and work with representative samples (Gerard et al., 2016), the challenge would be to ensure comparability: for instance scholars interested in e-WOM will increasingly resort to cross-platform cross-country studies whereby online customer behaviors will be compared (Mariani, Borghi and Kazakov, 2019) also controlling for mobile devices (Mariani, Borghi and Gretzel, 2019). Fourth, increasingly applied researchers might have access to (digital) data streams (Pigni et al., 2016) in real time. This might contribute to reduce the theory-practice divide in tourism management research through the generation of data-driven knowledge about markets and prospective customers that could be made actionable (in real time) by policy makers, destination managers (Deng et al., 2018), firms' executives, and entrepreneurs to create real time T\&H services (Buhalis and Sinarta, 2019). However, this would imply an increasing integration of $\mathrm{BD}$ and business intelligence applications (Fan et al., 2015). Fifth, BD analytics promise to enhance a number of digital technologies such as AI and the IoT that heavily rely on data. Indeed, beyond chatbots that are very rudimentary forms of AI, more advanced AI forms and applications increasingly need to be fed by $\mathrm{BD}$ to trigger learning processes that machines can use to learn from past and present customer behaviours to anticipate and identify future tourists' needs and engage with travellers. As such we envision that a new digital entrepreneurship field (Nambisan, 2017) might be shaped within the T\&H literature by focusing on the disruptions brought about by digital entrepreneurs in $\mathrm{T} \& \mathrm{H}$ services industries (Buhalis et al., 2019). This is particularly relevant as BD analytics is one of the digital technologies underpinning the Industry 4.0 (Rüßmann et al., 2015). The intertwined development of AI applied to data mining and predictive analytics might translate into developments of effective digital business models to support product, process and business model innovation.

\section{Conclusions}

In conclusion, there is an increasing scholarly awareness in the T\&H scientific domain that the complexity of today's phenomena need to be addressed be leveraging BD and BD analytics. It is envisioned that in the upcoming years BD will be increasingly adopted to enrich and corroborate research designs and generate findings that could be generalizable across different geographical and social settings. Data science skills and competences should be therefore embedded into crossdisciplinary research teams. The intertwined development of BD with AI and IoT technological paradigms will call for an even more integrated approach to the study of digital transformation and entrepreneurship within T\&H services.

\section{References}

Bello-Orgaz, G., Jung, J.J. and Camacho, D. (2016), "Social big data: recent achievements and new challenges", Information Fusion, Vol. 28, pp. 45-59.

Blazquez, D. and Domenech, J. (2018), "Big Data sources and methods for social and economic analyses", Technological Forecasting and Social Change, Vol. 130, pp. 99-113.

Buhalis, D., Harwood, T., Bogicevic, V., Viglia, G., Beldona, S., Hofacker, C., (2019), "Technological disruptions in Services: lessons from Tourism and Hospitality", Journal of Service Management, https://dx.doi.org/10.1108/JOSM-12-2018-0398

Buhalis, D. and Sinarta, Y. (2019), Real-time co-creation and nowness service: lessons from tourism and hospitality, Journal of Travel and Tourism Marketing, Vol. 36(5), pp. 563582.

Cox, M. and Ellsworth, D. (1997), "Managing Big Data for scientific visualization”, ACM Siggraph, MRJ/NASA Ames Research Center, Vol 5, pp. 1-17. 
Creswell, J. W. (2014), Research Design: Qualitative, Quantitative and Mixed Method Approaches. Fourth Edition, Sage Publications, Thousand Oaks, CA

Davenport, T.H. (2017), "How analytics have changed in the last 10 years", Harvard Business Review, June 2017.

Deng, N. and Li, X. (Robert). (2018), "Feeling a destination through the "right" photos: A machine learning model for DMOs' photo selection", Tourism Management, Vol 65, pp. 267-278.

Fan, S., Lau, R.Y. and Zhao, J.L. (2015), "Demystifying big data analytics for business intelligence through the lens of marketing mix", Big Data Research, Vol 2 No 1, pp. 28-32.

Fuchs, M., Höpken, W. and Lexhagen, M. (2016), Big Data and Business Intelligence in the Travel and Tourism Industry, Mid Sweden University, Östersund.

Gerard, G., Osinga, E.C., Lavie, D., and Scott, B.A. (2016), "Big data and data science methods for management research", Academy of Management Journal, Vol 59 No 5, pp. 1493-1507.

Hilbert, M. and López, P. (2011), "The World's Technological Capacity to Store, Communicate, and Compute Information", Science, Vol 332 No 6025, pp. 60-65.

IBM, 2016. Big Data and Analytics. http://www-01.ibm.com/software/data/bigdata/what-is-bigdata.html (accessed $27^{\text {th }}$ November, 2016)

Liu, Y., Tseng, F-M, and Tseng, Y-H. (2018), "Big Data analytics for forecasting tourism destination arrivals with the applied Vector Autoregression model", Technological Forecasting and Social Change, Vol. 130, pp. 123-134.

Mariani, M.M., Borghi, M. and Gretzel, U. (2019), "Online reviews: Differences by submission device", Tourism Management, Vol. 70, pp. 295-298.

Mariani, M.M. and Visani, F. (2019), "Embedding eWOM into efficiency DEA modelling: An application to the hospitality sector", International Journal of Hospitality Management, Vol. 80, pp. 1-12.

Mariani, M.M., Borghi, M. and Kazakov, S. (2019), "The role of language in the online evaluation of hospitality service encounters: An empirical study", International Journal of Hospitality Management, Vol. 78, pp. 50-58.

Mariani, M.M., Di Fatta, G. and Di Felice, M. (2019), "Understanding Customer Satisfaction with Services by leveraging Big Data: the Role of Services Attributes and Consumers' Cultural Background", IEEE Access, 7,8580523, pp. 8195-8208.

Mariani, M.M. and Borghi, M. (2018), "Effects of the Booking.com rating system: Bringing hotel class into the picture", Tourism Management, Vol. 66, pp. 47-52.

Mariani, M.M., Mura, M. and Di Felice, M. (2018), "The determinants of Facebook social engagement for national tourism organizations' Facebook pages: A quantitative approach", Journal of Destination Marketing \& Management, Vol. 8, pp. 312-325.

Mariani, M.M., Baggio, R., Fuchs, M. and Höpken, W. (2018). Business Intelligence and Big Data in Hospitality and Tourism: A systematic literature review. International Journal of Contemporary Hospitality Management, Vol 30 No 10, pp. 3514-3554.

Mariani, M.M., Baggio, R., Buhalis, D., and Longhi (2014), "Introduction”. In Mariani, M.M., Baggio, R., Buhalis, D., and Longhi, C. (eds.), Tourism management, marketing, and development: Volume I: The importance of networks and ICTs. New York: Palgrave, pp. 1-11 [DOI: 10.1057/9781137354358_1]

Pauleen D.J. and Wang W.Y.C. (2017), "Does big data mean big knowledge? KM perspectives on big data and analytics", Journal of Knowledge Management, Vol. 21 No.1, pp. 1-6.

Pigni F., Piccoli G. and Watson R. (2016), "Digital Data Streams: Creating value from the real-time flow of big data", California Management Review, Vol 58 No 3: pp. 5-25.

Rüßmann, M., Lorenz, M., Gerbert, P., Waldner, M., Justus, J., Engel, P., Harnisch, M., 2015. Industry 4.0: The Future of Productivity and Growth in Manufacturing Industries. Boston Consulting Group. Vol. 9.

Stylos, N. and Zwiegelaar, J. (2019). Big Data as a Game Changer: How Does It Shape Business IntelligenceWithin a Tourism and Hospitality Industry Context?. In Sigala, 
M., Rahimi, R. and Thelwall, M. (Eds.), Big Data and Innovation in Tourism, Travel, and Hospitality (pp. 163-181). Springer, Singapore.

Talón-Ballestero, P., González-Serrano, L., Soguero-Ruiz, C., Muñoz-Romero, S. and Rojo-Álvarez, J.L. (2018), "Using big data from Customer Relationship Management information systems to determine the client profile in the hotel sector", Tourism Management, Vol 68, pp. 187-197

The Economist, 2017. The world's most valuable resource is no longer oil, but data. https://www.economist.com/leaders/2017/05/06/the-worlds-most-valuable-resource-is-nolonger-oil-but-data (accessed $5^{\text {th }}$ June, 2019)

Xiang, Z., Du, Q., Ma, Y. and Fan, W. (2017), "A comparative analysis of major online review platforms: Implications for social media analytics in hospitality and tourism", Tourism Management, Vol 58, pp. 51-65. 